Matthias Egg

Scientific Realism in Particle Physics 


\section{Epistemische Studien}

Schriften zur Erkenntnis- und Wissenschaftstheorie

Herausgegeben von/Edited by

Michael Esfeld, Stephan Hartmann, Albert Newen

\section{Band 29}




\section{Matthias Egg}

Scientific Realism

in Particle Physics

A Causal Approach

DE GRUYTER 
ISBN 978-3-11-035439-3

e-ISBN 978-3-11-035440-9

ISSN 2198-1884

\section{Library of Congress Cataloging-in-Publication Data}

A CIP catalog record for this book has been applied for at the Library of Congress.

\section{Bibliographic information published by the Deutsche Nationalbibliothek}

The Deutsche Nationalbibliothek lists this publication in the Deutsche Nationalbibliografie; detailed bibliographic data are available on the Internet at http://dnb.dnb.de.

(c) 2014 Walter de Gruyter Inc., Boston/Berlin

Printing: CPI books $\mathrm{GmbH}$, Leck

(2) Printed on acid-free paper

Printed in Germany

www.degruyter.com 